\title{
The role of worship and ethics on the road towards reconciliation
}

B A Müller

(Emeritus, University of Stellenbosch)

\section{ABSTRACT \\ The role of worship and ethics on the road towards reconciliation}

Reconciliation in a divided society, like the South African one, is in dire need of a new moral discourse and praxis. This article argues that this moral discourse must also be conducted on an often forgotten level, namely in the worshipping praxis of the Church. The article describes the renewed interest of ethicists and liturgists in the relationship between liturgy and ethics and especially the role of rituals. The article then focuses on the renewal of basic Cristian rituals like preaching and sacraments, prayer and praise to serve this much needed moral discourse.

In 1982, a member Church of the Reformed Church family in South Africa formulated the Belhar Confession on unity, reconciliation and compassionate justice. In the Accompanying Letter, the intention of the Confession was stated very clearly: that "we can be free together and together may walk the road of reconciliation and justice" (cf Cloete \& Smit [eds] 1994 for both the text of the Confession and that of the Accompanying Letter). Was this "A long walk to freedom" (the title of Nelson Mandela's autobiography) a mere dream in the African reality of a broken society torn apart by racial, political and economic divisions? (On this "African reality" see Alberts \& Chicane 1991.) Meiring (2000:197f), Meiring argues that "the need for forgiveness and reconciliation is still with us" and, therefore, the "need for a moral order in South Africa is still with us" (On the role of the Church, see Durand 2002).

Although a "rainbow nation" was predicted after the apartheid and colonial rule had been demolished and replaced by democratic structures, the divisions persisted and the conflicts seemed to escalate. Today, people still live in different worlds, cultures, interest groups and economic strata ranging from the extremely wealthy to the "poorest of the poor", and they see life and the future in completely different ways. The violence experienced and "learned" over many centuries in Africa, often at the hands of colonial powers, 
persists and seems to resist being unlearned. The result is what Jones (1995:71f) calls an "eclipse of forgiveness", an "inescapable reality that persistently tears at the fabric of people's lives until everyone is diminished, if not destroyed, by it".

In this devastating cycle of violence, a moral discourse must be re-opened to strengthen the moral fibre of the new society. It will have to be a moral discourse using common moral grammar, a common moral language based upon new common stories of reconciliation that replace the old memories of the struggle period (see Smit 1995a:65-85, 1995b:85-107). Even more: moral practices are required in a situation of brokenness in the human community occasioned by disastrous "worlds in collision" - national and international, local and global.

In his Foreword to To remember and to heal the Right Reverend Dr Desmond Tutu (in Botman \&. Petersen 1996:8) writes: "Religion is central to this process of healing. We need to reach deep into the spiritual wells of our different religious traditions practised in this country in order to draw the strength and grace with which to address the challenges of healing and nation building". This paper will try to voice the Christian tradition's dream of reconciliation as an alternative to violence, of a vision of "the reconstruction and reconciliation of one of the most divided, alienated, and violent societies, in which ethnic and cultural differences continue to threaten the fragile sense of nationhood" (Petersen, in Botman \& Petersen [eds] 1996:60; see also Van Reisen 1984:93).

Several editions of sermon-helps published in South Africa under the title, Woord teen die lig, Deel III provide a clear insight into the type of moral discourse that should be conducted in the homiletical situation (see especially the introduction to Riglyne vir prediking oor Christelike deugde, in Burger, Müller \& Smit [eds] 1996:10-36). In 2002, the Beyers Naudé Institute for Public Theology was inaugurated at the University of Stellenbosch with the specific aim to discern new focal points in this moral discourse and to serve the creation of a new ethos as part and parcel of a public theology that will empower Christians and Church structures to be agents of an integrated reconciliation process - a reconciliation clearly expressed in the words of the now well-known Belhar Confession. In the past decade, a whole chorus of young emerging ethicists in South Africa showed a renewed and varied interest in an ethics of being, of character, of identity and discipleship-formation 
as prerequisites for the transformation of a violent society and the reconstruction of a new society (Smit 1997:25).

I believe that these discourses must be conducted at another, often forgotten, level. Thereby I want to take up the challenge of a suggestion by the editors of Sermon helps on preaching virtues (Burger, Müller \& Smit [eds] 1996:15), namely, to reflect on the relationship between liturgy and ethics. After a very general introduction on the subject, consideration will be given for the role of rituals of reconciliation as "rites of passage" practised in liminal situations whereby worshipping communities could anticipate and celebrate the coming together of God's new world (2 Cor 5:17), the birth of God's new humanity (Eph 2:14). In the third part, a summary will be given of existing and emerging rituals of reconciliation in African, especially South African contexts.

\section{ON LITURGY AND ETHICS}

Paul Ramsay's (1979:139 ev) article on "Liturgy and ethics" was a clear call to think more clearly and incisively about the interrelationship of worship and morality. In 1980, Wainwright (1980:8) maintained that worship "is the point of concentration at which the whole of Christian life comes into ritual focus". In the same vein, Senn (1997:xiii) declares that "liturgy is the church's public presentation of its beliefs and enactment of its life" whereby it proclaims and celebrates the good news of forgiveness, reconciliation and a new life.

In a special issue of Theology Today, Long (1991:3) says correctly: "long before worship is an experience, it is a way of behaving, an ethic, a pattern of life that demands training and discipline". In the same issue Wolterstorff $(1991: 6,7)$ suggests that "part of what identifies the Christian church as a distinct people in history is that it engages in the Christian liturgy" and that, "liturgy and justice...meant somehow to interact with each other, expressing and nourishing each other... The Church is to gather for the celebration of the liturgy, and when it is dispersed is to practice and to struggle for justice and to spread the Word about its Lord". Referring to the liturgical function of the book of Revelation, Kellerman (1991:5) says, "Liturgy signifies and celebrates the end of one world and the beginning of another. In that sense faithful worship is inherently subversive". (In this connection, see Berrigan 1983; on "worship as political rehearsal" see Everett 1999:27f; as 
well as Yoder 1991:33-44; and Wannenwetsch 1996:85). Wolterstorff $(1991: 9,10)$ then makes this serious concluding statement that "liturgical actions lose their authenticity when those who participate in the liturgy do not practise and struggle for justice... liturgy in the absence of justice does not please God; it nauseates God". Unfortunately this was true of many worship services in South Africa, as the research over two decades by Müller and Smit (1991:652-665) has clearly shown. Müller and Smit (1994:385-408) show that less than $10 \%$ of all the services broadcasted in this period had, in some way, focused on ethical issues, such as justice, peace, reconciliation, etc, because worship often legitimises society and endorses societal values instead of subverting and criticizing them. Best and Heller (1995:xii) claim that there is a need "to develop more fully the relationship of worship to work for justice, witness and service".

Already in 1963, Vaticanum II, in Sacrosanctum Concilium $\mathrm{I}: 1.10$, stressed that the liturgical activity of the Church is the source of both the missional outreach and the moral praxis of the Church. In the same way the World Council of Churches (WCC 1964:paper 42) described worship as "the central and determinative act of the Church's life". Therefore, Höfte (1984:93 ev) quite justifiably speaks of "liturgie als oefenplaats van vrede en gerechtigheid". In the same volume, Wegman (in Höfte 1984:13) writes: "Heel langzaam wordt de liturgie weer ontdekt als plaats waar waarachtigheid kan en moet worden geleerd, waar vrede en gerechtigheid kunnen worden ingeoefend". This emphasis was adopted by liturgists, such as Everett (1999:305) who regards worship as a "rehearsal of God's right order", and especially by Don Saliers (1994a \& 1994b) who has focused intensively on the way worship shapes our entire motivational and emotional structure.

This liturgical focus has been reinforced by drawing on the work of anthropologists, such as Mary Douglas (1982) and Victor Turner (1969), to name but a few, who made an enormous impact on both Roman-Catholic and Protestant liturgical studies. They see worship as a natural part of human life, as the means by which communities preserve their key values and orientations, pass them on and deal with the anxiety provoked by war, disease, conflict and life situations, especially in times of transition.

Also in the work of ethicists, such as Hauerwas (1981) and Westerhoff (1985), worship is perceived to be a process in which 
communities create virtues in their members through a kind of learning process that conditions them to certain habits, orientations and perceptions. Hauerwas (Hauerwas \& Willimon 1989:95) states: "Ethics is a way of seeing before it is a matter of doing. The ethical task is not to tell you what is right or wrong, but rather to train you to see. That explains why, in the Church, a great deal of time and energy is spent in the act of worship. In worship, we are busy looking in the right direction". Lukken (1994:102f) agrees herewith that liturgy helps us to see things in perspective, a perspective that leads to deeper insight. (See 1994:140f on the relation between "sagen" and "sehen"). The perspective of an ethics of character, of a community of disciples and saints, tells and retells the foundational story of the Jesus event, and reverberates in the ongoing narrative of the Church. Smit (1997:1f) has consistently underlined this and says, inter alia: "Christian ethics depends fundamentally on seeing, on perception...the moral dilemmas we perceive depend upon the persons we are. Recognition depends on character" (See also Vosloo 1994; and Müller 2002:197 ev).

Now, since 1995, in Princeton, Wuthnow (1998) has argued that we need social contexts or specific "localities" where we learn to see and learn to care. Gregory Jones (1995:2,121 ev), in the same year, stressed that we need these localities because "the activity of moral judgment is inextricably tied to particular social contexts and is decisively affected by the presence or absence of theological convictions" - contexts where the moral order is learned and sin is unlearned. This learning and unlearning occur through what he calls "pedagogies of discipleship" - specific kinds of practices. Now, I want to argue that Christian worship is one of these specific locations where the faithful are trained to see, to look in the right direction, to see the world sub specie Christi (Bonhoeffer 1959:7 ev). Höfte (1984:105) argues in the same vein that the sacramentalliturgical praxis must be situated in the "koinoniale praxis dat elke structuur en vormgeving van de christelijke gemeente doortrokken is". Worship services must be regarded as such locations, where a common moral language is learned, where bad habits are unlearned, where responsible people are formed and where an ethics of being and character is cultivated, articulated, narrated and celebrated. In his valuable study on transforming a people of God, Grierson (1984:11) correctly concluded that the formation and the transformation of a congregation depend on the formation and 
transformation of its culture, its ability to envision and embody a style of life that is a distinctively Christian confession of human existence - and that this is shaped by a corporate view in which shared images and ideas are learned in a complex of interweaving relationships and sustained by the repetition of focal words and ritual events. Pfatteicher (1995:90f) makes very valuable suggestions regarding these formative aspects of worship by underlining various instructive features of worship of which we should take note in faith and moral formation.

Finally, it can be noted that Jörns (1988:12-22) underlined this renewed emphasis on the ethical dimension of worship by adding to the well-known lex orandi - lex credendi the lex convivendi. In his publications, Wainwright (1995:99) has continually emphasized this integral relationship between worship and ethics, prayer and Word, which belong together where the "euchological and the ethical are subsumed in a single doxology" and "the lex orandi and the lex credendi remain incomplete without a corresponding lex bene operandi" (see also Wainwright 1991:604). Indeed, the ways in which Christians worship not only determines how they believe, but also how they live together. By establishing, affirming and reaffirming the Christian faith in the liturgical celebration and retelling its founding story, it helps to provide identity, character and direction to the community of the faithful. By liturgical revisioning, alternative visions are opened - also in the midst of the so-called "African reality". Van Reisen (1984:13) summarizes it well: "Vanuit de liturgie waarin de Schriften worden voorgelezen over de vrede en het koninkrijk van God, zullen degenen die die liturgie vieren, gaan ervaren wat zij vieren, hun gebed ermee vullen, hun leefstijl veranderen". In referring to Mowickel's emphasis on cultic acts as doors to alternative worlds and realities, Brueggemann (1988:6f) states correctly, "liturgy must be constitutive, next to being responsive". He continues on $\mathrm{p} 30$ : "the process of world-construction, in Israel and elsewhere, is a liturgical process". Like narratives, the liturgy mediates reality by redescribing it (see Wilder 1983:358 ev).

\section{THE ROLE OF RITUAL IN THE LIFE OF WORSHIPPING COMMUNITIES - A SUMMARY}

In this limited article, it is not my intention to discuss at length the value of ritual in liturgical celebration and in faith formation. The results of profound research on the essence and function of ritual 
have been published worldwide, especially in this journal. On the role of ritual in general and in worship in particular, see the excellent summary by Lukken (1994:88-117 and 1999:105-144; see also Post, Rouwhorst, Van Tongeren \& Scheer [eds] 1999:10 note 11; and Rouwhorst 2000:71-85). On the Dutch research program see especially Post (in Post et al 1999:51f; Barnard \& Post 2001; and Barnard \& Schuman [eds] 2002). Because very little research has been done on ritual in general in South Africa, thorough cognisance should be taken in African contexts of these highly academic and profound practical reflections (see Hanekom 1995). The role that ritual can play in moral discourses and discernments can be summarized as follows:

(a) As stated above, worship is an enactment of an anamnetic moral discourse linking what the Church was in the past, to what it is in the present, and what it should become in the future. Ritual spells out and activates the dream of this ever-renewed reality. Linking past, present and future that helps to find healing, may be called the dynamic aspect of ritual (see Botman, in Botman \& Petersen [eds] 1996:38,58-60).

(b) According to Lukken $(1994: 102,115)$, rituals are windows, they open deeper realities, disclose farther horizons, offer wider landscapes in an imaginative way. He describes the ethical function of ritual well: "ritual is a window through which one, so to speak, perceives unsuspected perspectives and enters into something of that other reality in life...without rituals, access to the deeper...Christian reality ultimately remains closed off'. Because rituals penetrate life itself, they can help us to come to terms with dark, frightening, violent, unforgiving, irreconcilable, impenetrable issues in life. How can rituals do this? Again, quoting Lukken (1994:30), "In and through ritual people let go of their own capacities. They permit the reality, which surpasses their own existence. They seek access to the divine course...to the renewing power of mystery. They express hope that the future should be greater". Rituals function eschatologically as the praxis of faith working through love to generate and sustain hope! The enactment of ritual strengthens the bond of unity and love, thereby enhancing the healing of relationships in an often dehumanised, immoral context of chaos.

(c) Rituals act as collective representations that provide an identity to groups of believers, shaping new worlds for these groups, thereby shaping their behaviour, helping them, through liturgical response, to 
respond morally in an ordered pattern. Uzukwu (1997:43) sees the importance of ritual in an African context by describing rituals as "instruments of social engineering" and ethical reform. In this sense, Grierson (1984:45) quite rightly regards the function of rituals as "subtle and elusive webs of meaning that bind together the inner life of a community". By re-establishing the covenant through ritual celebration, the life of the community and its commitment to the moral order, on which it has been founded, are renewed, again and again.

(d) In the ever-changing ecclesial and socio-cultural contexts, this renewal must remain relevant and dynamic in a dialogue of cult and culture. There is a great need for in-depth liturgical research to be done in this respect in the South African and African contexts.

(From a general African perspective, see Uzukwe 1997; Lumbala 1998; Chupungo 1992; ibid, in Best \& Heller [eds] 1995; ibid, in Stauffer [ed], 1996; Stauffer, in Best \& Heller 1995; ibid 1996b:181-188; and Lutheran World Federation 1998:244-252. On "the explosion of literature with regard to liturgical inculturation", see Post (1999a:53 note 15.)

\section{RENEWAL OF BASIC CHRISTIAN RITUALS IN THE MINISTRY OF RECONCILIATION}

We now take a closer look at the possibilities of rituals, old and new, to enhance a transformation process, in their confrontation with new cultures, contexts and cults - dealing especially with reconciliation in its broader and narrower sense. Especially in Africa, there is a renewed insistence "for the creation of new rituals responding to local needs". This renewed insistence was greatly motivated and promoted by Sacrosanctum Concilium, No 63b of Vatican II. In Africa, Christianity must offer a Christian anchor in the "anthropological switch" to these emerging rituals. (On the "anthropological Wende" see Post 2002:15f). The basic Christological emphasis on Word and sacrament, in ritual and life, is essential: it declares God's loving forgiveness for all (Eph 2:14f), thereby consistently and persistently breaking down barriers. Both Word and sacrament must proclaim the Christian message of reconciliation, so well expressed in Colossians 1:19, 20: "through Him [i.e. Christ] God was pleased to reconcile to Himself all things". Jones (1995:120) puts this well: "In the midst of the brokenness of human community occasioned by universal and ongoing disaster of both 
personal and structural sin, Christ draws others into communion with Him and with one another".

\subsection{Ritual and preaching of the Word}

With regard to moral issues, the role of preaching the Word has been widely discussed. In South Africa, the homiletic research up to the present is largely dominated by problems relating to the relation between law and gospel, especially with regard to preaching on moral issues. For an overview, see the Introduction to Burger, Müller and Smit (1996), and Cilliers (2000). In this respect, it must be noted that within traditional African ritual, as in their Christian worship, the word always comes first. Words must give meaning to ritual gesture. Lumbala (1998:33) says: "In Africa it is certainly true that the word takes a place of honor". In Cameroon, mass starts with a consecration of the Bible; in other African congregations the service begins with the presiding elder carrying the Bible on his head when entering the Church. In preaching on issues of character-formation, not only of individuals, but also of Christian communities, called to live faithfully before God (see Mi 6:8) this ethical dimension must receive attention. The life of these Christian communities must be formed, transformed and regulated by a contextual interpretation of Scripture as the normative canon for the Church. This interpretation, therefore, must take place in communion, while engaging in the hard process of conversation, argument, discussion and dialogue in prayer and practice. The homiletical interpreter must learn to understand and interpret the text through the eyes of the "other": the estranged, the enemy, the underdog. But remember: it is important not only to read, interpret, understand and hear the Scriptures in community. In order to become a community of character, these scriptural texts must also be performed in community. In and through sermons, we learn to see, but also to act differently.

This is well argued by Fowl and Jones (1991). See also Wannenwetsch (1996:288) on the importance of "hearing in community". De Gruchy (2000:vii) says that "the title... sums up a central theme in the Christian gospel, namely that we are called 'to become like children' in order to see things from a totally different perspective, that is, the perspective of God's gracious reign over the whole of reality."

Preaching, as such, needs to remember not only the importance of reading, interpreting, understanding and hearing the Scriptures in 
community, but actually performing them in a community of character. This will have to be the subject of a separate discussion.

\subsection{Baptism as rite of initiation, participation and recon- ciliation}

According to Romans 6.3f, as the sacrament of initiation into the new community of faith, baptism must be seen as the "foundation for the Christian life... a prophetic sign...under which the whole Christian life is to be lived" (Witvliet 1997:57; see Calvin, Instit iv. 15.3). In a very real sense, the Christian community lives ad fontes. This is the fountain which constitutes the congregation as ecclesia, and which forms the anchor of its life and hope. Through baptism, a very real transition takes place from one world to the next. Here, Christians are initiated into the new people of God, thereby entering into a covenant with God. Therefore, baptism "sets the believer on the brink of lifelong service and commitment" (Witvliet 1997:158; see also Everett 1999:75). In his very informative study on baptism, Lukken (1994:167) very clearly stresses the social implications of baptismal participation in the redemptive work of Christ on the Cross and in His Resurrection (see also Van Reisen 1984:96f). While embodying the life of the new man in Christ, and that of the new community, baptism has a deep moral drive towards realising the full humanity in Christ (see Eph 2:13f). The ritual of baptism makes each believer a participant in God's new order of righteousness, justice, forgiveness and reconciliation. Therefore Jones (1995:166) argues that the sacramental action of baptism in, and into, the Church gives rise to an 'ongoing process of 'living into your baptism', of learning to appropriate God's forgiveness through repentance and discipleship". See also Müller (2002:205) on the need for rituals of "reaffirmation" of baptism. This is a process whereby our forgivenness must inevitably lead to concrete discipleship of forgiven and forgiving people. This baptismal participation in forgiveness and forgiving requires an unlearning of all that divide and destroy communion between people; through baptism they are liberated from the structures of sin and evil, of being victimizers and victims in the one baptized community. In a dehumanized and dehumanizing context, baptism, as a sign of a lifelong reconciliation, calls us to this redeemed and healed community.

In the sacrament of the "one baptism", whether they are of different sex, race, culture and social contexts, believers are brought into the one body of Christ, and thereby into the common life of the 
believing community (Eph 4:5,6; Gl 3:25,26). The Lima text on Baptism, Eucharist and Ministry states very clearly: "baptism is a sign and seal of our common discipleship...our common baptism, which unites us to Christ in faith, is thus a basic bond of unity... When (this) baptismal unity is realized in one, holy catholic, apostolic Church, genuine Christian witness can be made to the healing and reconciling love of God" (WCC 1982:par 6). No wonder then that Uzukwu (1997:229), in the African context of violence and victimization, calls for a renewal of baptism that takes cognizance of the positive role of the initiation practice in African societies. He proposes, inter alia, baptismal practices "that would give greater human density to the truth (of baptism) being communicated". (For examples of inculturation, see Lumbala 1998:12f.) However, this will require a creative reworking of Christian baptism in a theological sense, appropriating the wealth of (rapidly disappearing) African rites of initiation and naming ceremonies whereby believers can be grafted into the social customs, memories, traditions and expectations of a close-knit local congregation. When these initiation and naming practices enrich our baptismal rites, greater "human density" will be reached in which the local community not only accepts and welcomes the newly baptized, but also takes the responsibility of guiding and disciplining the baptized into the lifestyle and ethos of the Christian community. Uzukwu (1997:274) describes the naming practices in many parts of Africa, whereby a child receives two names: one denoting his/her familial relationship, the other containing a sign or a promise into which he/she must grow up in future.

\subsection{The Eucharist}

In one of the earliest writings on the relation between the Eucharist and ethics, St Paul writes in 1 Corinthians 11:27-29 about "discerning the body" of Christ, about eating the bread and drinking the cup "in an unworthy manner". This clearly argues for a manner of life, an ethic that corresponds to the celebration of the Eucharist. "It is in the eucharist that the Church is most truly at home with God, and learns to know most truly who she is. The Church's identity which allows her to be the true sign is pregnantly actualized in the eucharist" (Wainwright 1997:176). The Eucharistic communion with Christ nourishes this identity and, at the same time, nourishes the communion within his body, which is the Church, demonstrating the 
unity of the partakers. Therefore, the BEM document, paragraph 20, states a blunt consequence:

The Eucharistic celebration demands reconciliation and sharing among all those regarded as brothers and sisters in the one family of God and is a constant challenge in the search for appropriate relationships in social, economic and political life... All kinds of injustice, racism, separation and lack of freedom are radically challenged when we share in the body and blood of Christ.

In this spirit, Calvin admonished the celebrants at Holy Communion to give themselves to one another as members of Christ's body (Inst. iv.17.40). Schreiter (1992:75-76) states more clearly: "Gathering around the eucharistic table, the broken, damaged, and abused bodies of individual victims and the broken body of the Church are taken up into the body of Christ... "The need for reconciliation brings a new urgency to the celebration of the Eucharist". The same is heard from a Protestant angle when Wainwright (1997:210f) views the Eucharist as allowing us to learn, absorb, and extend the values of God's kingdom. "The eucharistic paradigm points us in the right direction (of justice, peace and joy): it sets the vector within which the difficult concrete decisions and actions of everyday life have to be taken and performed if they are to be authentically Christian". As early as in Didache 14 the author wrote: Let no one who has quarrel with his companion join with you until they have been reconciled, that your sacrifice may not be defiled. Clearly, confession and reconciliation were conditions for the celebration of the Eucharist. No wonder that, at present, there is a veritable wave of writings connecting the Eucharist with ethics and economics. Yoder (1991:36) regards "the eucharist as an act of economic ethics". (In general, see Cochrane 1974; Fox 1998; and Willimon 1981). In the Eucharistic celebration, this ethical emphasis must be seen in an eschatological frame:

De eucharistische verdichting van de koinonia is niet alleen de verkondiging van de dood van de Heer totdat Hij komt, maar ook fundamenteel de anticipatie van deze komst en van de uitnodiging tot vreugde aan de armen omwille van de hoop op een nieuwe hemel en een nieuwe aarde. De eucharistische koinonia als de gevierde en uitgezongen gemeenschap van de volgelingen in en met de Heer is het symbool, het sacrament van de uiteindelijke koinonia die 
geanticipeerd en historisch bemiddeld wordt in de gemeenschap van de volgelingen en in de diaconia met de armen. Op de derde plaats betekent koinonia, in en door de zusterlijke en broederlijke gemeenschap en in en door de gemeenschap met Jezus, gemeenschap met de God van het rijk.

(Höfte 1984:99)

From this Eucharistic centre, nourished in its own identity, the Church can take the world onto its agenda, working actively for the healing and renewal of the broken humanity and world.

In parts of South Africa and in Africa in general, there is a renewed emphasis on the Eucharist as a crucial and fundamental ritual, so important in the life of the Church. The Eucharist is very often enriched by the typical African culture of family bonds of fellowship and hospitality. The Eucharistic celebration, excluding all types of discrimination, forms a bond between believers and is, therefore, widely celebrated especially by small groups living in hostile and often violent contexts. Here, the Eucharistic symbols of a home and a meal play a central role in the celebrations. For the African, "to share a meal is to share a relationship, to share life" (Uzukwu 1997:265). Therefore, a meal is always served as part of the Eucharistic celebration, "as the expression and instrument of the communion and solidarity" (Lumbala 1998:32). At an African meal, a stranger is accepted as a member of the family; at a meal, the hungry are fed; in the home, a homeless person is sheltered and a displaced person is given an address; at a meal, a covenant of solidarity is sealed. When the Eucharistic celebration applies all this, it receives a new human density and moral intensity. When the sign of peace is given prior to the meal, not only is a new covenant of reconciliation and retribution given but, as a witness, the community will ensure that the covenant is adhered to. In Zimbabwe, the Eucharist celebrates, at the same time, reconciliation with the earth when congregations of the African Independent Churches plant new trees at the conclusion of their services. In a more general way, especially in South Africa with its history of deep divisions between races, communities - and Churches! - partaking of the same bread and wine has become a central and dynamic part of ecumenical and Church unification services. Churches design various rituals to lament the brokenness of the body of Christ, which partakers 
experience so dramatically at the table: the symbol of an unlit candle, an empty chair, a broken cross to signify the heartrending absence of brothers and sisters of the same family - or a moment of silence when the congregation stares at an open door in expectation of the lost brother and sister to come home....

\subsection{Rituals of confession and forgiveness}

The ritual of penitence, confession and remission of sins should be performed between the rituals of baptism and the Eucharist: it enhances the baptismal conversion and "growing into" baptism and, therefore, acts as a preparation for coming to the table. This can be seen as a "second baptism". Smit (1996:103) says that the full act of reconciliation "is the heart of the Christian Gospel. God reconciled the world with Godself in Christ. God took mercy on the unjust, the guilty, in fact on God's enemies. And the Christian Church has been given this message of reconciliation to proclaim and administer... first forgiveness, then acknowledgement of guilt". Therefore, on page 115, he contends that "the Christian convictions about confession - guilt — truth — and forgiveness can still help societies in many ways" by embodying confession in openness to the truth with courage and commitment, by listening to stories of hurt and pain and sharing them in the community of forgiveness. Lumbala (1998:58) states that "rites of reconciliation are among the most important rites in Black Africa, because on them depend the restoration and maintenance of life in the community. In fact, our societies do not depend on technical structures, but on alliances and the communion of groups....Rites of reconciliation in our African societies are fundamental'". Uzukwe (1997:282f) describes the Iqaba ndu ritual to resolve a conflict and healing relationships by tokens of covenant making. Jennings (1988:67-68) says the same in a more general way:

In the act of confession, we become those who "see clearly" both ourselves and the world in which we are implicated. This clarifying of our perception occurs, let us remember, in the light of the hoped-for liberation.... It is as we hope for freedom that bondage comes more clearly into view. It is because we hope for justice that injustice is seen more starkly. It is in the light of a promised peace that enmity stands out sharply. Hope is not a sedative that tranquilises us in the face of the world's pain, brokenness, and bondage. It is instead that which for the first time genuinely awakens us to 
our situation... The confession of sins is the point at which we identify the ways we need and require that which God promises for us and for the world. In the confession of sin, we act out this awareness. Thus, indirectly, we describe ourselves as those who were blind but are now beginning to see.

The practice of confession is never an "excuus" (see Nauta 2001:1133), nor only the banishment of illusion, self-deception, dishonesty, or hypocrisy by which we hide from God or our neighbour...but the realization of a new world in Christ. This should happen more and more in various ways in the Christian worship. But we must remember: these rituals of confession have to deal with $\sin$, sin in its vertical and horizontal aspects, which touches those near to us, those who are vulnerable and can be hurt. It twists the order of society. A wrong once committed, even in private, is a disorder that is introduced into the social fabric. Therefore, the repair of the wrong must be public, must be a community affair. In this respect, we can refer to many ways in which the Church in Africa has expanded the scope and focus of rituals of penance to various forms of healing of disharmony between individuals, married couples, disputing families and clans (for valuable information on this, see Uzukwu 1997:254f; and Lumbala 1988:69f). We must realize that healing, whether physical, emotional or social, always takes place in the community, as the guardian of peace and general well-being. In the services of the African Independent Churches, healing, divining and exorcism have an integral function in almost all services.

In his masterful study on embodying forgiveness, Jones (1995:210f; see also 219f) also focuses on the role of narratives in learning "the craft of forgiveness, inter alia through contextualizing forgiveness in the broader patterns of life". In this respect, in South Africa, we have experienced that the stories, emanating from the hearings of the Truth and Reconciliation Committee (TRC), found their way back to the Church and its worship services - worship services in which forgiveness was embodied in a great variety of ritual expressions: times of silence, specific confessions, forgiveness asked and given in an atmosphere of broken spirits (On the impact of the TRC on Church life, see Alberts \&. Chikane 1991; De Gruchy 1993:3-13; Smit: 1995a:3-15; South African Council of Churches 1989). From a black perspective Thlagale (1986) has valuable suggestions. The TRC Report $(1998,65 \mathrm{f})$ has also very interesting 
information on the role of faith communities especially the findings and suggestions of the commission (91 \& 92). Rituals are in the process of being developed where the truth of our divisions are admitted, lamented and confessed in the unity worked by the Holy Spirit - the only way that the "truth can be spoken in love". In the discussions on the reuniting of The Dutch Reformed Church in South Africa and the Uniting Reformed Church, delegates were given the opportunity to design symbols and rituals that could be used in the tough process towards unity.

\subsection{Rituals of prayer, praise and lament}

Of course, prayer was one of the main elements in the Jewish cultic tradition: prayers of praising and blessing God but also prayers of contrition and supplication. The life of the believer coram Deo found expression in the prayers and praise of the Psalms. For Brueggemann, the praise of Israel is the beginning of a political praxis: praise gives to liturgy not only its appropriative function, but also a transforming one, a destabilizing and subversive dynamic. In the Psalter, Israel's energetic and transformative memory was embedded in an ongoing cultic pattern (see Brueggemann 1988:56f). In New Testament times, the doxological praises of Jesus as Lord (Phlp 2:11) and the prayers of the Church (see Ac 1:14, 4:23f, 6:4; Rv 5:8f, etc) kept the memory of the Jesus event alive. Prayer is indeed a way of thinking our way into God's way and God's world (the title of Hall 1987). In this connection, Nouwen (1998:17) says, "prayer is the basis of all peacemaking precisely because in prayer we come to the realization that we do not belong to the world in which conflicts and war take place, but to Him who offers us his peace". In discussing the role of public prayer as a ritual of reconciliation, we must heed the advice in James 5:13-18, where the healing power of prayer is connected to the confession of sin. In the Prayer for Africa services held in South Africa, prayer and confession go hand in hand, on the public podium and in small groups.

Too often, services of praise and worship lack the element of lament. In lament, we move from muteness to awareness, openness to the truth of our lives, individually and together. Lament, says Ackerman (1996:52), is a "crucial step in the process of reconciliation". We need to lament the injustice, the unreconciled situations of violence, in their most vicious but also in their subtle forms. These laments are ways to deal with the past and with the 
present. Unfortunately, lamentation seems to have disappeared from our praise, prayers and worship. In old Israel the lament was very much part of the songs and prayers of praise (see Ex 2:23,24; Ps $32: 5$; 51, etc). Like God's people of old, we can raise our voices in lament, as part of our worship, in seeking the reconciliation we all need so desperately! In South Africa, these voices crying out in lament have become very much part of combined worship services and Days of Prayer for Africa.

\section{THE CHURCH AS SACRAMENT OF RECONCILIA- TION-IN-UNITY}

Ultimately, the Church in itself, in its pluriform manifestations from synodal gatherings to daily life, is a sign and seal of Christ's presence in this world, of Christ "als Gemeinde existierend" (Bonhoeffer). Somehow, the Church, in itself, is the sacramental embodiment of unity, reconciliation and justice. And this sacramental identity and life of the Church is to be manifested in ever new, relevant, dynamic embodiments, in thousand fold ways always in their historical, cultural and social contexts. It is most noteworthy that an edition of sermon-helps for preaching on the unity of the Church in South Africa deals with the identity of the Church, in terms of its witness and its credibility in the world. Burger et al (1997:12) correctly states: "Die punt wat hierdie boek wil maak, is dat goeie werk op die vlak van ander belangrike sake verydel kan word - nee: verydel sal word! - as die kerk van Christus in ons land nie daarin slaag om meer van sy eenheid sigbaar te maak nie". Interestingly enough, these sermon-helps deal precisely with the ethical matters discussed in this paper: unity and reconciliation; unity and guilt; unity and service in love; unity and mission; and unity and a new creation. Then it continues on the level of celebrating this unity: sermons on worship, on the one baptism and unity and on the unity at the Eucharistic table.

The confession of this unity makes reconciliation between divided Churches and groups in society crucially important: reconciliation between Christians, between Churches and traditions, is the key to reconciliation between races and conflicting groups. I want to argue that, in liturgical assemblies, the celebration of this reconciliation should, therefore, play a key role in this unity becoming visible and thereby becoming an example in a world of contrasts and collisions. The marks of the Church as one, holy, 
catholic, and apostolic Church are found in the Nicene Creed. Battle (1997:119) comments:

Tutu adds another mark, liturgy, which denotes the work of the people and the rites of public worship. Thus, Tutu maintained that in order for true change to occur in South Africa, the church must be unashamedly itself through the particular nature and work of liturgy. But he cautioned, 'God will not accept worship, however meticulously correctly performed unless it has affected the life of the people in their everyday concerns, particularly showing mercy and doing justice' (Is 1, 58)".

The Church is, first and foremost, a worshipping community - and proper, complete and authentic worship can only take place where Christians are united in faith and life, fundamentally shaped by their corporate worship (see Wainwright 1980:viii, 1 \& 127f). Eriksen and Lindner (1997:23-24) summarize this well:

Drawing on the community's gathered spiritual energies, utilizing its diverse cultural resources, tapping the deepest reservoirs of its collective memory, worship has formed, expressed and celebrated the community's identity in an especially potent way...[it] offers an experience of redemptive reconciliation...serves as the mortar that holds together the bricks of ecumenical formation.

On the other hand, how can we expect to overcome divisions of life and death and violence of global format that play havoc between individuals, generations, sexes... and nations when believers and the Church in general are not even able to proclaim and offer together the good news of the sacrifice of the Lord, who gave His life for the salvation of the world? I believe, therefore, that we must revert to the centre of our ministry, of Word and sacrament, enacting the central Jesus event, celebrated in the liturgy and in the life and mission of the Church. And, from that celebration and feast, we must go out into the world to work and pray actively for the renewal of our human community, in every possible context. It is only the Church which goes out from this liturgical centre of Word and sacrament, thereby strengthened in its own identity, that can put a dehumanized world central on its agenda. Because: "There will never be a time when the world ceases to be the agenda of the Church. The Church living ever more deeply in its own identity can 
go out to the edges of society, not fearful of being distorted and confused by the world's agenda, but confident that God is already in the midst ahead" (Tanner (1984:49). Liturgy and ritual help the Church to focus on this central event, to orientate its life and mission on Christ and thereby to re-orientate its ethos centripetally.

\section{Consulted literature}

Ackerman, D 1996. On hearing and lamenting. Faith and truthtelling, in Botman, H R \& Petersen R M (eds) 1996: 47-56.

Alberts, L \& Chicane, F 1991. The road to Rustenberg. The Church looking forward to a new South Africa. Cape Town: Mercer.

Baptism, Eucharist and Ministry 1982. Faith and Order Paper no 111. Geneva: WCC.

Barnard, M \& Post, P 2001. Ritueel bestek. Anthropologische kernwoorden van de liturgie. Zoetermeer: Meinema.

Barnard, M \& Schuman, N 2002.Nieuwe wegen in de liturgie - een vervolg. Zoetermeer: Meinema.

Battle, M 1997. Reconciliation. The ubuntu theology of Desmond Tutu. Cleveland:Pilgrim Press.

Berrigan, D 1983. The nightmare of God. Portland:

Best, T F \& Heller, D (eds) 1995. So we believe, so we pray. Geneva: WCC.

Bonhoeffer, D 1959 [2004]. Creation and fall. Minneapolis: Fortress.

Botman, H R \& Petersen, R M 1996. To remember and to heal. Cape Town: Human and Rousseau.

Brueggemann, W 1988. Israel's praise Doxology against idolatry and ideology. Philadelphia: Fortress.

Burger, C W, Muller, B A \& Smit, D J 1996. Riglyne vir prediking oor die Christelike deugde, in Woord teen die lig III/4. Kaapstad: Lux Verbi.

Burger, C W, Muller, B A \& Smit, D J 1997. Riglyne vir prediking oor die eenheid van die kerk, in Woord teen die lig III/5. Kaapstad: Lux Verbi

Chupungo, A J 1992. Liturgical inculturation: sacramentals, religiosity and cathechesis. Minnesota: Liturgical Press.

-, 1995. Liturgical inculturation and the search for unity, in Best, T F \& Heller, D (eds) 1995, Paper 171.

-, 1996. Two methods in liturgical inculturation, in Stauffer (ed) 1996a, 77-94.

Cilliers, J 2000. Die genade van gehoorsaamheid. Wellington: BM.

Cloete, G D \& Smit, D J 1994. A moment of truth. Grand Rapids: Eerdmans.

Cochrane, A 1974. Eating and drinking with Jesus. Philadelphia: Fortress.

De Gruchy, J W 1993. Guilt, amnesty and national reconstruction, in JSAT 83: 3-13. 
-, 2000. Seeing things differently. Cape Town: Mercer.

Douglas, M 1982. Natural symbols. Explorations in cosmology. New York: Oxford University Press.

Durand, J J F 2002. Ontluisterde wêreld. Die Afrikaner en sy kerk in 'n veranderende Suid-Afrika. Wellington: BM.

Eriksen, J H \& Lindner, E W 1997. Worship and prayer in ecumenical formation, in Theological Education 34: 23-30.

Everett, W J 1999. The politics of worship. Reforming the language and symbols of liturgy. Cleveland: United Church Press.

Fox, N 1998. Church in the daily meal: the ordinance of the breaking of bread. New York: Oxford Univ Press.

Fowl, S E \& Jones, L G 1991. Reading in communion. Scripture and ethics in Christian life. Grand Rapids: Eerdmans.

Grierson, D 1984. Transforming a people of God. Melbourne: Joint Board of Education.

Hall, D J 1987. When you pray. Thinking your way into God's world. Valley Forge: Judson.

Hanekom, A R 1995. Simbool en ritueel as instrument van geloofsvorming. Unpublished doctoral dissertation, University of Stellenbosch.

Hauerwas, S 1981. A community of character. Towards a constructive social ethics. Notre Dame: Notre Dame University Press.

Hauerwas, S \& Willimon, W H 1989. Resident aliens. Nashville: Abingdon.

Höfte, B 1984. De voorwaarden voor liturgie als oefenplaats van vrede en gerechtigheid: een perspectief voor een pastorale praxis van heil en bevrijding, in Van gerechtigheid tot liturgie (Inleiding Van Reissen, H) 1984, 93-108.

Jennings, T 1988. The liturgy of liberation. Nashville: Abingdon.

Jones, L G 1995. Embodying forgiveness. A theological analysis. Grand Rapids: Eerdmans.

Jörns, K P 1988. Lex orandi - lex credendi - lex convivendi, in: Der Lebensweg des Gottesdienstes. München: Kaiser, 12-22.

Kellerman,W 1991. Seasons of faith and conscience. Kairos, confession, liturgy. Maryknoll: Orbis.

Long, T G 1991. Liturgical stormclouds, in Theology Today 48: 1-5.

Lukken, G 1994. Per visibilia ad invisibilia (eds van Tongeren, L \& Caspers, C). Kampen: Kok.

-, 1999. Rituelen in overvloed. Een kritische bezinning over de plaats en de gestalte van het christelijk ritueel in onze cultuur. Baarn: Gooi en Sticht.

Lumbala, F K 1998. Celebrating Jesus in Africa. Liturgy and inculturation. Maryknoll :Orbis. 
Lutheran World Federation 1998. Nairobi statement on worship in: Studia Liturgica 28: 244-252.

Meiring, P 2000. Truth and reconciliation. The South African experience, in Van Vugt, W E \& Cloete, G D (eds). Race and reconciliation in South Africa: a multicultural dialogue in comparative perspective. London: Lexington.

Müller, B A \& Smit, D J 1991. Godsdiens in die openbaar. Tendense in die Afrikaanse godsdiensprogramme van die SAUK, in NGTT, 652-665.

-, 1994. Public worship - a tale of two stories, in Mouton, J \& Lategan, B C (eds ). The relevance of theology for the ninetees. Pretoria: Unisa, 385-408.

Müller, B A 2002. Liturgical and homiletical revisioning to generate hope for a just society, in Dreyer, T F \& Van der Ven, J A (eds) Divine justice - human justice. Pretoria: HSRC, 197-214.

Nauta, R 2001. Excuus, pardon, vergeef me, het spijt me. Exercities in de excuus cultuur. Nijmegen: Valkhof.

Nouwen, H 1998. The road to peace. Maryknoll: Orbis.

Petersen, R M 1996. The politics of grace and the TCR, in Botman, H R \& Petersen, R M (eds) 1996, 57-64.

Pfatteicher, P H 1995. The school of the Church. Worship and christian formation. Valley Forge: Trinity Press.

Post, P, Rouwhorst, G, van Tongeren, L \& Scheer, A (eds) 1999. Christian feast and festival. Leuven: Peters.

Post, P 1999a. Liturgical movements and feast culture. A Dutch programme, in Post et al 1999, 3-46.

-, 1999b. Introduction and application: feast as a key concept in a liturgical studies research design, in Post et al 1999, 47-78.

-, 2002. Life cycle rituals: a ritual-liturgical perspective, in Questions Liturgiques 83/1.

Ramsey, P 1979. Liturgy and ethics, in Journal of Rel Ethics, 139-171.

Rouwhorst, G 2001. Rituelen in overvloed, in Praktische Theologie 28/1: 7185.

Saliers, D E 1994a. Worship as Theology. Foretaste of glory divine. Nashville: Abingdon.

-, 1994b. Worship come to its senses. Nashville: Abingdon.

Schreiter, R J 1992. Reconciliation. Mission and ministry in a changing social order. Maryknoll: Orbis.

Senn, F C 1997. Christian liturgy. Catholic and Evangelical. Minneapolis: Fortress.

Smit, D J 1995a. Het Suid-Afrika 'n gemeenskaplike taal nodig?, in Herv Teol Studies 15/1: 65-85. 
-, 1995b. Oor die skepping van 'n grammatika van saamleef, in Herv Teol. Studies 15/1: 85-107.

-, 1995c. TheTruth and Reconciliation Commission - tentative religious and theological perspectives, in JSAT, 3-15.

-, 1996. Confession - guilt - truth and forgiveness in the christian tradition, in Botman, H R \& Petersen, R M (eds) 1996, 96-117.

-, 1997. Liturgy and life. On the importance of worship for christian ethics, in Scriptura 62: 259-280.

South African Council of Churches 1989. Confessing guilt in South Africa. The responsibility of Churches and individuals. Braamfontein: SACC.

Stauffer, S A 1995. Worship in culture, in Best, T F \& Heller, D 1995, Paper no 171.

-, 1996a. Christian worship: unity in cultural diversity. Geneva: Lutheran World Federation.

-, 1996b. Worship and culture. An international Lutheran study, in International Review of Missions 85, 181-183.

Tanner, M 1984. Unity and renewal: the Church and the human community, in Ecumenical Review 36/1984: 252-262.

Thlagale, B 1986. Hammering swords into spades: essays in honor of Archbishop Desmond Tutu. Cape Town.

Truth and Reconciliation Commission of South Africa, 1998. Report 4. Cape Town: CTP Book Printers.

Turner, V W 1969. The ritual process. Structure and antistructure. Chicago: Aldine.

Tutu, D 1996. Foreword, in Botman, H R \& Petersen, R M (eds) 1996, 7-14.

Uzukwu, E E 1997 .Worship as body language. Introduction to christian worship: an African orientation. Minnesota: Liturgical Press.

Yoder, J H 1991. Sacrament as social process. Christ as transformer of culture, in Theology Today 48: 33-44.

Van Reissen, H 1984. Van gerechtigheid tot liturgie. Hilversum: Gooi en Sticht.

Vosloo, R 1994. Verhaal en moraal. ' $n$ Kritiese ondersoek na die narratiewe etiek van Stanley Hauerwas. Unpublished doctoral thesis, University Western Cape.

Wainwright, G 1980. Doxology. The praise of God in worship, doctrine and life. London: Epworth.

-, 1991. Lex orandi, lex credendi, in Dictionary of the ecumenical movement. Geneva: WCC.

-, 1995. Methods in dialogue. Nashville: Abingdon.

-, 1997. Worship with one accord. Where worship and ecumenism meet. New York: Oxford Univ Press. 
Wannenwetsch, B 1996. The political worship of the Church: critical and empowering, in Modern Theology 12/3: 269-299.

Westerhoff, J 1985. Living the faith community. The church that makes a difference. Minneapolis: Winston Press.

Wilder, O 1983. Stories and storyworld, in Interpretation 37: 353-364.

Willimon, W H 1981. Sunday dinner. Nashville: Abingdon.

Witvliet, J D 1981. Baptism as sacrament of reconciliation in the thought of Johannes Calvin, in Studia Liturgica 27: 152-164.

Wolterstorff, N 1991. Justice as a condition of an authentic liturgy, in Theology Today 48: 6-21.

World Council of Churches 1964. The fourth conference on faith and order Montreal 1963. London: WCC Paper 42.

Wuthnow, R 1995. Learning to care. Elementary kindnessin a culture of indifference. New York: Oxford Univ Press. 